\title{
HUBUNGAN PEMBERIAN ASI EKSKLUSIF DALAM PRESPEKTIF SOSIAL BUDAYA DI KOTA PALEMBANG
}

\author{
Nur Alam Fajar, ${ }^{1}$ Dadang Hikmah Purnama, ${ }^{2}$ Suci Destriatania, ${ }^{3}$ Nurna Ningsih ${ }^{4}$ \\ ${ }^{1,3}$ Fakultas Kesehatan Masyarakat Universitas Sriwijaya, \\ ${ }^{2}$ FISIP Universitas Sriwijaya, \\ ${ }^{4}$ Program Studi Keperawatan Fakultas Kedokteran Universitas Sriwijaya \\ RELATIONSHIPS OF EXCLUSIVE BREASTFEEDING IN SOCIOCULTURAL \\ PERSPECTIVE IN PALEMBANG
}

\begin{abstract}
Background: Nationally, exclusive breastfeeding in 2010 to 2012 only reached 33,6-35\% that was caused by interactions of several social factors, demographic condition, biological issues, pre-and postnatal problems, and psychological issues. Despite that many studies have shown that exclusive breastfeeding will give a lot of health benefits to babies and moms, this has not always resulted the expected outcome. Advances in this modern era might also become one of the contributing factors to social, cultural and economic changes, thus causing the decline in supports to breastfeeding moms. The data taken from the Survey on Indonesian Health Demography in 2007 shows that exclusive breastfeeding in Indonesia had declined as much as 30,2\% and increase in formula as much as $11 \%$ in 2013. This study aimed to explain the relationships of exclusive breastfeeding seen from sociocultural perspectives in Palembang.

Methods: This study used a cross-sectional design to analyze the behavior of Early Initiation of Breastfeeding and Exclusive Breastfeeding for mothers whose her children aged 6-26 months in several communities in Palembang.

Results: Based on bivariate analysis was this study are 220 respondents. The analysis found that the number of children $(0,003<0,05)$, supports from mother or mother in law $(0,001<0,05)$, and ignorance $(0,020<$ $0,05)$ are correlated to exclusive breastfeeding, while families that keep themselves informed since pregnancy and postnatal period do not show significant relationships $(0,253>0,05)$ with exclusive breastfeeding. Conclusion: The results of the relationship analysis showed that respondents who had a number of children $\leq 2$ people, husband support and in-laws support were significantly related to exclusive breastfeeding to infants. While mothers who did not seek information, the level of knowledge of mothers, the type of work of the mother and the attitude of the mother did not show a relationship to exclusive breastfeeding in infants. Keywords: Exclusive breastfeeding, socio-cultural perspective
\end{abstract}

\begin{abstract}
ABSTRAK
Latar Belakang: Pemberian ASI eksklusif secara nasional pada tahun 2010-2012 hanya 33,6-35\% yang dipengaruhi oleh interaksi dari berbagai faktor sosial, demografi, biologi, pre dan postnatal, dan psikologi. Meskipun berbagai studi menunjukkan bahwa Pemberian ASI Eksklusif dapat memberikan manfaat kesehatan pada bayi maupun ibunya, namun hasilnya belum sesuai dengan yang harapkan. Kemajuan modernisasi merupakan salah satu penyebab terjadinya perubahan sosial, budaya maupun ekonomi, sehingga dampaknya berpengaruh terhadap menurunnya dukungan pada ibu menyusui. Data Survei Demografi Kesehatan Indonesia Tahun 2007 menunjukkan bahwa pemberian ASI eksklusif mengalami penurun sebesar $30,2 \%$ dan peningkatan pemberian susu formula sebesar $11 \%$ pada tahun 2013. Penelitian ini bertujuan untuk menjelaskan hubungan perilaku Pemberian ASI Eksklusif berdasarkan perspektif sosial budaya di Kota Palembang.

Metode: Penelitian ini menggunakan analisis cross sectional yang bertujuan menjelaskan hubungan perilaku Pemberian ASI Eksklusif berdasarkan perspektif sosial budaya di Kota Palembang. Hasil Penelitian: Sampel penelitian ini berjumlah 220 responden. Hasil analisis tersebut menunjukkan bahwa jumlah anak ( $\mathrm{p}$-value $=0,003$ ) dukungan ibu atau mertua ( $\mathrm{p}$-value $=0,001$ ) memiliki hubungan signifikan dengan pemberian ASI Eksklusif pada bayi, sedangkan jenis pekerjaan, pendidikan istri, pendidikan suami, komposisi keluarga, pengetahuan ASI eksklusif dan sikap ibu tidak memiliki hubungan yang signifikan $(\mathrm{p}>0,005)$ terhadap pemberian ASI eksklusif pada bayi.
\end{abstract}

\footnotetext{
${ }^{1}$ Alamat Koresponding: Nur Alam Fajar, Fakultas Kesehatan Masyarakat Universitas Sriwijaya, Jl. Palembang Prabumulih KM. 32, Indralaya Indah Kabupaten Ogan Ilir, Sumatera Selatan, Email: nuralamfajar@fkm.unsri.ac.id
} 
Kesimpulan: Hasil analisis hubungan menunjukkan responden yang memiliki jumlah anak $\leq 2$ orang, dukungan suami dan dukungan mertua, tidak mencari informasi berhubungan secara signifikan terhadap pemberian ASI eksklusif pada bayi. Sedangkan ibu yang berhubungan,tingkat pengetahuan ibu, jenis pekerjaan ibu dan sikap ibu tidak menunjukkan adanya hubungan terhadap pemberian ASI eksklusif pada bayi.

Kata Kunci: Asi eksklusif, perspektif sosial budaya

\section{PENDAHULUAN}

Inisiasi Menyusui Dini (IMD) adalah suatu upaya mengembalikan hak bayi yang selama ini terenggut oleh para praktisi kelahiran yang pada saat membantu proses persalinan. Kondisi ini dapat menurunkan ketahanan tubuh bayi hingga 25 persen dan bahkan bayi dapat mengalami goncangan psikologis akibat kehilangan perlindungan dari ibunya sehingga dapat mempengaruhi kualitas perkembangan fisik, psikologis, dan kecerdasan anak dikemudian hari. Pemahaman dan pelaksanaan yang baik tentang Inisiasi Menyusui Dini merupakan dasar utama dan kuat dalam proses tumbuh kembang anak dan pemenuhan Air Susu Ibu sejak bayi lahir sampai usia 6 bulan akan meningkatkan poin kecerdasan intelektual yang lebih tinggi sebesar 12,9 pada usia 9 tahun. ${ }^{1}$

Inisiasi Menyusui Dini bukan saja menyukseskan pemberian ASI eksklusif tetapi juga memperlihatkan hasil nyata dalam menyelamatkan nyawa bayi, dan apabila semua bayi segera setelah lahir diberi kesempatan menyusui sendiri dengan membiarkan kontak kulit antara ibu ke kulit bayi minimal selama satu tahun maka satu juta nyawa bayi dapat diselamatkan ${ }^{1}$. Hasil penelitian menunjukkan bahwa IMD dapat mengurangi angka kematian neonatal sebesar $22 \%$ dan di berbagai negara berkembang IMD dapat menghemat sekitar 1,45 juta jiwa setiap tahun. Berdasarkan hasil penelitian di Bolivia dan Madagaskar diketahui bahwa seperempat sampai setengah dari kematian bayi di negara berkembang terjadi pada minggu pertama kehidupan. $^{2} \quad$ Berbagaipenelitian telah $^{2}$ mengkaji manfaat Pemberian Asi Eksklusif sebagai upaya menurunkan mortalitas dan morbiditas bayi, mengoptimalkan pertumbuhan bayi, membantu perkembangan kecerdasan anak, dan membantu memperpanjang jarak kehamilan. ${ }^{3}$

Penelitian di Timur Tengah menemukanhanya $6 \%$ ibu menyusui bayinya pada lima jam pertama kelahiran,71,6\% setelah 36 jam kelahiran dan sebagian besar(90\%) dua hari setelah kelahiran. ${ }^{3}$ IMD yang tertunda sangat dipengaruhi oleh pengetahuan dan faktor sosial budaya lainnya. Data UNICEF menunjukkan bahwa angka cakupan praktik IMD di Indonesia dari tahun 2003 hingga 2008 sebesar 39\% dan cakupan ASI eksklusif selama enam bulan sebesar 40\%. Sementara itu hasil Riskesdas juga menunjukkan bahwa persentase IMD sebesar $29,3 \%$ lebih rendah dari tahun 2008. Berbagai faktor disinyalir sebagai penyebab rendahnya perilaku IMD di Indonesia, antara lain karena faktor tingkat pendidikan, sikap, dan motivasi ibu menyusui yang kurang dipengaruhi oleh perilaku dan tindakan bidan serta dukungan dari keluarga.

Menurut Simanjuntak bahwa penyebab kegagalan praktek ASI eksklusif bermacammacam, seperti pemberian makanan prelakteal, ibu harus bekerja, bayi sakit, faktor kelelahan atau kurang percaya diri dari ibunya, dan lain sebagainya. Penelitian ASUH tahun 2002 menunjukkan bahwa bukan semata-mata faktor pengetahuan ibu yang mempengaruhi keberhasilan ASI ekslusif, tetapi juga berbagai faktor sosial budaya di masyarakat yang mempengaruhi keberhasilan ASI eksklusif.

Faktor lain yang mempengaruhi keberhasilan Pemberian Asi Eksklusif adalah kemampuan untuk melakukan penyusuan segera (immediate breastfeeding) yang saat ini 
lebih dikenal dengan istilah Inisiasi Menyusui Dini. ${ }^{4}$ Salah satu kunci utama keberhasilan IMD terletak pada penolong persalinan karena dalam menit-menit pertama setelah bayi dilahirkan peranan penolong persalinan sangat dominan. Menyusui adalah perilaku kesehatan multi dimensional yang dipengaruhi oleh interaksi dari berbagai faktor demografi, biologi, psikologi, dan sosial budaya. Berbagai faktor inilah yang bersifat modificable dan unmodificable sehingga banyak literatur yang menampilkan hubungan kausal antara beberapa faktor terhadap keberhasilan ibu dalam memberikan ASI ekslusif dan beberapa faktor lainnya yang menampilkan hasil yang inkonsisten terhadap keberhasilan ibu dalam memberikan ASI eksklusif. $^{5}$

Berdasarkan hasil penelitian pemantauan status gizi yang dilakukan di Propinsi Sumatera Selatan tahun 2015 diketahui bahwa hanya 50,9\% ibu melahirkan yang melakukan IMD di Kota Palembang dan begitu juga status gizi balita sangat kurang berdasarkan indeks $\mathrm{BB} / \mathrm{TB}$ tertinggi justru ditemukan di Palembang sebanyak 2,8\%. Oleh karena itu dianggap perlu untuk mengetahui model perilaku IMD dan Pemberian ASI Ekslusif di Kota Palembang dalam upaya mengatasi berbagai permasalahan kesehatan balita yang nantinya akan ditindaklanjuti melalui pendekatan promotif dan preventif (Dinkes Propinsi Sumatera Selatan, 2016)

\section{METODE}

Penelitian ini bersifat mix method dengan menggunakan metode observasional analitik, yaitu rancangan cross sectional untuk menganalisis perilaku Inisiasi Menyusui Dini dan Pemberian ASI Eksklusif pada ibu yang memiliki anak usia 6-26 bulan di beberapa komunitas yang ada Kota Palembang serta didukung oleh data kualitatif melalui Focus Group Discussion (FGD) dan In depth Interview yang hasilnya ditafsirkan secara content analysis untuk menjelaskan model perilaku Inisiasi Menyusui Dini dan Pemberian Asi Eksklusif berdasarkan perspektif sosial budaya yang turut mempengaruhinya.

Penelitian ini dilakukan di beberapa komunitas yang ada di Kota Palembang, seperti Ogan, Bugis, Arab, Cina, Jawa, Padang, Batak, dan yang lainnya dimana pelaksanaannya direncanakan dalam tahun 2016. Populasi adalah seluruh ibu yang memiliki anak usia 6-24 bulan dan belum diketahui jumlahnya. Besar sampel minimal dalam analisis faktor adalah 50 pengamatan, namun aturan umum mensyaratkan bahwa sedikitnya ada 5 responden untuk setiap variabel, artinya bahwa jika variabel di dalam penelitian ini berjumlah 10 maka besar sampel minimal yang digunakan adalah $5 \times 10$ variabel yaitu 50 responden. Pada penelitian ini akan dianalisis berbagai hal yang menghambat dan yang mendorong dari berbagai perspektif sosial budaya yang menentukan terlaksana atau tidaknya perilaku Inisiasi Menyusui Dini dan Pemberian ASI Eksklusif berdasarkan pada masing-masing komunitas tersebut.

Selanjutnya sampel akan diambil dengan menggunakan teknik cluster random sampling dengan hirarki sebagai berikut :

a. Tahap Pertama yaitu melakukan pemilihan cluster pada setiap strata. Stratifikasi yang digunakan adalah komunitas lokal dan pendatang yang mempunyai ibu pasca melahirkan antara 1-6 bulan, dan setiap strata akan dilakukan pemilihan cluster yang akan dilakukan secara probability proportionateto size (PPS) terhadap sejumlah ibu pasca melahirkan dengan menggunakan aplikasi komputer Berdasarkan teknik pps ini maka setiap komunitas akan memiliki kesempatan yang sama untuk terpilih sebagai cluster.

b. Tahap Kedua yaitu dilakukan pemilihan responden di setiap cluster terpilih kemudian pemilihan tersebut akan dilakukan dengan teknik purposive random sampling yang artinya bahwa setiap ibu 
akan mempunyai kesempatan yang sama untuk terpilih sebagai responden berdasarkan kriteria inklusi sebagai berikut:

1) Ibu yang memiliki anak usia 6-24 bulan

2) Berumur 17 atau lebih dan mendapatkan izin dari suami atau keluarga.

3) Berdomisili di Palembang dan bersedia untuk dijadikan sebagai responden.

Analisis kualitatif digunakan dalam studi formatif untuk mengetahui pengaruh tokoh kunci dalam perilaku Inisiasi Menyusui Dini dan Pemberian ASI Eksklusif, serta beberapa faktor penghambat dan pendorong yang dirasakan oleh informan melalui dukungan faktor sosial budaya pada masingmasing komunitas tersebut. Hal ini juga sejalan dengan hasil analisis univariat, dan bivariat, tentang perilaku Inisiasi Menyusui Dini dan Pemberian ASI Eksklusif berdasarkan perspektif sosial budaya pada masing-masing komunitas yang ada di Kota Palembang.

\section{HASIL PENELITIAN}

Tabel 1.

Karakteristik Responden

\begin{tabular}{|c|c|c|c|}
\hline Karakteristik & kategori & $\mathrm{n}$ & $\%$ \\
\hline \multirow[t]{3}{*}{ Pekerjaan } & Bekerja di luar rumah & 16 & 7,3 \\
\hline & Wirausaha & 28 & 12,7 \\
\hline & Tidak bekerja & 176 & 80 \\
\hline \multirow[t]{3}{*}{ Pendidikan istri } & Dasar (SD, SMP) & 56 & 25,5 \\
\hline & Menengah (SMA,SMK) & 122 & 55,6 \\
\hline & Tinggi (PT) & 42 & 19,1 \\
\hline \multirow[t]{3}{*}{ Pendidikan suami } & Dasar (SD, SMP) & 52 & 23,6 \\
\hline & Menengah (SMA,SMK) & 121 & 55,0 \\
\hline & Tinggi (PT) & 47 & 21,4 \\
\hline \multirow[t]{2}{*}{ Jumlah anak } & $\leq 2$ anak & 144 & 65,5 \\
\hline & $>2$ anak & 76 & 34,5 \\
\hline \multirow[t]{2}{*}{ Komposisi keluarga } & Keluarga besar & 116 & 52,7 \\
\hline & Keluarga kecil (keluarga inti) & 104 & 47,3 \\
\hline \multirow[t]{4}{*}{ Agama } & Budha & 9 & 4,1 \\
\hline & Islam & 189 & 85,9 \\
\hline & Katolik & 5 & 2,3 \\
\hline & Protestan & 17 & 7,7 \\
\hline \multirow[t]{8}{*}{ Komunitas } & Arab & 28 & 12,7 \\
\hline & Palembang & 29 & 13,2 \\
\hline & Bugis & 28 & 12,7 \\
\hline & Jawa & 27 & 12,3 \\
\hline & Cina & 26 & 12,7 \\
\hline & Padang & 26 & 11,8 \\
\hline & Batak & 27 & 12,3 \\
\hline & Sunda & 27 & 12,3 \\
\hline \multirow[t]{2}{*}{ Asi eksklusif } & Tidak asi eksklusif & 66 & 30 \\
\hline & Asi eksklusif & 154 & 70 \\
\hline
\end{tabular}

Berdasarkan Tabel 1 hasil karakteristik diketahui bahwa sebagian besar responden memberikan ASI eksklusif pada bayinya (70\%). Responden secara umum merupakan ibu yang tidak bekerja (80\%). Secara umum tingkat pendidikan istri berada pada tingkat pendidikan menengah $(55,6 \%)$ begitu pula dengan tingkat pendidikan suami $(55 \%)$.
Dilihat dari jumlah anak sebanyak $65,5 \%$ responden memiliki jumlah anak $\leq 2$ orangpersentase responden yang tinggal bersama anggota keluarga lainnya selain anggota keluarga inti sebanyak 52,7\%. Berdasarkan karakteristik sosial budaya, mayoritas responden adalah pemeluk agama islam (85,9\%). Responden yang termasuk 
komunitas Arab, Bugis, dan Cina yaitu sebesar 12,7\%, komunitas Jawa, Batak, dan Sunda sebesar 12,3\%, komunitas padang sebesar 11,8\%, dan komunitas palembang sebesar $13,2 \%$.

Tabel 2.

Proporsi Berdasarkan Komunitas

\begin{tabular}{|c|c|c|c|c|c|c|}
\hline \multirow[t]{3}{*}{ Komunitas } & \multicolumn{4}{|c|}{ ASI Eksklusif } & \multirow{2}{*}{\multicolumn{2}{|c|}{ Total }} \\
\hline & \multicolumn{2}{|c|}{ Tidak ASI } & \multicolumn{2}{|c|}{ ASI } & & \\
\hline & $\mathbf{n}$ & $\%$ & $\mathbf{n}$ & $\%$ & $\mathbf{n}$ & $\%$ \\
\hline Arab & 8 & 28,6 & 20 & 71,4 & 28 & 100 \\
\hline Palembang & 8 & 27,6 & 21 & 72,4 & 29 & 100 \\
\hline Bugis & 9 & 32,1 & 19 & 67,9 & 28 & 100 \\
\hline Jawa & 8 & 29,6 & 19 & 70,4 & 28 & 100 \\
\hline Cina & 12 & 42,9 & 16 & 57,1 & 28 & 100 \\
\hline Padang & 7 & 26,9 & 19 & 73,1 & 26 & 100 \\
\hline Batak & 9 & 33,3 & 18 & 66,7 & 27 & 100 \\
\hline Sunda & 5 & 18,5 & 22 & 81,5 & 27 & 100 \\
\hline Total & 66 & 30.0 & 154 & 70,0 & 220 & 100 \\
\hline
\end{tabular}

Berdasarkan Tabel 2 hasil analisis bivariat diketahui bahwa terdapat hubungan yang signifikan $(\mathrm{p}=<0,05)$ antara jumlah anak $(\mathrm{p}=0,024)$, dukungan suami saat melahirkan $(\mathrm{p}=0,004)$, dukungan ibu/ibu mertua $(\mathrm{p}=<0,001)$, dan tidak mencari informasi $(\mathrm{p}=0,024)$ terhadap perilaku pemberian ai eksklusif pada bayi. Sedangkan jenis pekerjaan, pendidikan istri, pendidikan suami, komposisi keluarga, pengetahuan asi eksklusif, sikap ibu tidak memiliki hubungan yang signifikan $(p>0,005)$ terhadap pemberian asi eksklusif pada bayi.

Tabel 3.

Distribusi Faktor Pemberian ASI Eksklusif

\begin{tabular}{|c|c|c|c|c|c|c|}
\hline \multirow[t]{2}{*}{ Variabel } & \multirow[t]{2}{*}{ Kategori } & \multirow[t]{2}{*}{$\mathbf{N}$} & \multicolumn{2}{|c|}{ Asi eksklusif } & \multirow[t]{2}{*}{ PR } & \multirow[t]{2}{*}{ Nilai p } \\
\hline & & & Ya & Tidak & & \\
\hline \multirow[t]{3}{*}{ Jenis pekerjaan } & $\begin{array}{l}\text { Bekerja diluar } \\
\text { rumah }\end{array}$ & 16 & 4 & 12 & $\begin{array}{c}1,190 \\
(0,367-3,867)\end{array}$ & 0,772 \\
\hline & Wirausaha & 28 & 12 & 16 & 0,529 & 0,127 \\
\hline & Tidak bekerja & 176 & 50 & 126 & $(0,234-1,198)$ & \\
\hline \multirow[t]{3}{*}{ Pendidikan istri } & Dasar & 56 & 14 & 42 & $\begin{array}{c}1,065 \\
(0,426-2,660)\end{array}$ & 0,894 \\
\hline & Menengah & 122 & 41 & 81 & 0,701 & 0,374 \\
\hline & Tinggi & 42 & 11 & 31 & $(0,320-1,535)$ & \\
\hline \multirow[t]{3}{*}{$\begin{array}{l}\text { Pendidikan } \\
\text { suami }\end{array}$} & Dasar & 52 & 15 & 37 & $\begin{array}{c}0,943 \\
(0,393-2,266)\end{array}$ & 0,896 \\
\hline & Menengah & 121 & 38 & 83 & 0,835 & 0,636 \\
\hline & Tinggi & 47 & 13 & 34 & $(0,396-1,760)$ & \\
\hline \multirow[t]{2}{*}{ Jumlah anak } & $\leq 2$ Anak & 144 & 51 & 93 & 2,230 & 0,024 \\
\hline & $>2$ Anak & 76 & 15 & 61 & $(1,153-4,315)$ & \\
\hline \multirow[t]{2}{*}{$\begin{array}{l}\text { Komposisi } \\
\text { keluarga }\end{array}$} & Keluarga Besar & 116 & 40 & 76 & $\begin{array}{c}1,579 \\
(0,879-2,837)\end{array}$ & 0,166 \\
\hline & Keluarga Kecil & 114 & 26 & 78 & & \\
\hline \multirow[t]{2}{*}{$\begin{array}{l}\text { Pengetahuan } \\
\text { ASI Eks }\end{array}$} & Rendah & 91 & 33 & 58 & $\begin{array}{c}1,655 \\
(0,925-2,963\end{array}$ & 0,120 \\
\hline & Tinggi & 129 & 33 & 96 & & \\
\hline \multirow[t]{2}{*}{ Sikap Ibu } & $\begin{array}{l}\text { Tidak } \\
\text { mendukung }\end{array}$ & 130 & 42 & 88 & $\begin{array}{c}1,313 \\
(0,724-2,378)\end{array}$ & 0,454 \\
\hline & Mendukung & 90 & 24 & 66 & & \\
\hline \multirow{2}{*}{$\begin{array}{l}\text { Dukungan } \\
\text { Suami } \\
\text { kelahiran }\end{array}$} & $\begin{array}{l}\text { Tidak } \\
\text { mendukung }\end{array}$ & 80 & 34 & 46 & $\begin{array}{c}2,495 \\
(1378-4515)\end{array}$ & 0,004 \\
\hline & Mendukung & 140 & 32 & 108 & & \\
\hline
\end{tabular}




\begin{tabular}{|c|c|c|c|c|c|c|}
\hline \multirow[t]{2}{*}{$\begin{array}{l}\text { Dukungan } \\
\text { Ibu/Mertua }\end{array}$} & $\begin{array}{l}\text { Tidak } \\
\text { mendukung }\end{array}$ & 78 & 37 & 41 & \multirow[t]{2}{*}{$\begin{array}{c}3,516 \\
(1,923-6,429)\end{array}$} & \multirow[t]{2}{*}{$<0,001$} \\
\hline & Mendukung & 142 & 29 & 113 & & \\
\hline \multirow[t]{3}{*}{$\begin{array}{l}\text { Sumber } \\
\text { Informasi }\end{array}$} & $\begin{array}{l}\text { Tidak mencari } \\
\text { informasi }\end{array}$ & 22 & 11 & 11 & \multirow{3}{*}{$\begin{array}{c}0,354 \\
(0,144-0,871) \\
0,511 \\
(0,205-1,275)\end{array}$} & 0,024 \\
\hline & $\begin{array}{l}\text { Setelah } \\
\text { persalinan }\end{array}$ & 22 & 9 & 13 & & 0,150 \\
\hline & $\begin{array}{l}\text { Sejak masa } \\
\text { kehamilan }\end{array}$ & 176 & 46 & 130 & & \\
\hline
\end{tabular}

Table 3. menunjukkan bahwa ibu yang memiliki jumlah anak $\leq 2$ orang memiliki risiko untuk tidak memberikan ASI eksklusif sebesar 2,23 kali dibandingkan ibu yang memiliki jumlah anak lebih dari 2 orang. ibu yang tidak mendapatkan dukungan dari suami saat melahirkan berisiko 2,495 kali untuk tidak memberikan ASI eksklusif pada bayi dibandingkan ibu yang mendapat dukungan suami saat melahirkan. Responden yang tidak mendapatkan dukungan dari ibu/ibu mertua berisiko untuk tidak memberikan ASI eksklusif sebanyak 3, 516 kali dibandingkan responden yang mendapat dukungan ibu/ibu mertua. Sedangkan responden yang tidak mencari informasi mengenai ASI eksklusif memiliki risiko 0,354 kali lebih kecil untuk tidak memberikan ASI eksklusif dibandingkan ibu yang mencari informasi mengenai asi eksklusif.

\section{PEMBAHASAN}

Berdasarkan hasil penelitian menunjukkan bahwa hanya $70 \%$ dari responden yang memberikan ASI eksklusif pada bayinya. Hal ini menunjukkan bahwa praktek pemberian ASI eksklusif di kota Palembang masih belum mencapai target yang menjadi indikator Indonesia sehat tahun 2015 dengan target yaitu $80 \%$. Penelitian ini sejalan dengan data Dinas Kesehatan kota palembang (2014) bahwa cakupan pemberian ASI eksklusif pada bayi 0-6 bulan belum mencapai target Nasional (74,18\%). Rekomendasi pemberian ASI eksklusif sampai usia 6 bulan tampaknya masih terlalu sulit untuk dilaksanakan. Sasaran program perbaikan gizi masyarakat untuk meningkatkan ASI eksklusif hingga $80 \%$ tampak terlalu tinggi. Padahal, pemberian asi eksklusif pada bayi akan memberikan dampak yang luas terhadap status gizi bayi dan ibu dikemudian hari. ${ }^{6}$
Pemberian ASI eksklusif merupakan hal yang penting, bertahan lama, dan suatu intervensi dengan biaya yang murah, yang dapat mengurangi angka morbiditas dan mortalitas pada bayi. $^{7}$

Pemberian ASI eksklusif oleh responden yang memiliki jumlah anak $\leq 2$ orang berhubungan secara signifikan terhadap pemberian ASI eksklusif pada bayi. Hal ini sejalan dengan hasil penelitian yang dilakukan oleh Fikawati dan Syafiq bahwa ibu yang memberikan ASI eksklusif rata-rata memiliki paritas yang lebih tinggi tinggi (3 anak) dari pada ibu yang tidak memberikan asi eksklusif (2 anak). Hal ini disebabkan jumlah anak akan berpengaruh terhadap pengalaman ibu mengenai menyusui. ${ }^{4}$

Berdasarkan hasil analisis bivariat terdapat hubungan yang signifikan antara dukungan suami saat melahirkan dengan pemberian ASI eksklusif pada bayi. Hal ini sejalan dengan apa yang dikemukakan dengan paramita bahwa seorang suami yang mampu memperlihatkan rasa sayang dan perhatian kepada ibu bisa mengakibatkan seorang ibu merasa lebih nyaman dan menghasilkan ASI yang berlimpah, serta akan meningkatkan rasa percaya diri ibu. Seperti yang terdapat dalam beberapa cuplikan hasil in depth interview berikut ini :

“ Alhamdulillah, bapa'e banyak bantu...dio yang masa'i daun katu untuk ningkatkan asi$k u \ldots .(w d) "$

“...ASI saya banyak karena mas Yudi sering membelikan cemilan kacang-kacangan... (ss) ",

Dukungan suami berupa kehadiran saat melahirkan dapat memberikan keuntungan 
emosional atau berpengaruh pada tingkah laku ibu yaitu pemberian ASI eksklusif. supporting father atau dukungan suami akan memberikan dukungan kepada ibu saat melahirkan dan membangun kepercayaan diri ibu agar mau dan mampu menyusui. ${ }^{9}$

Dukungan ibu/ibu mertua juga memberikan hubungan yang signifikan terhadap pemberian ASI eksklusif pada bayi. Ibu yang dipengaruhi oleh ibu/ibu mertua yang tidak mendukung pemberian ASI eksklusif akan lebih mudah berisiko untuk tidak memberikan ASI eksklusif pada bayinya. Hal ini karena adanya peran orang tua/mertua lebih besar dari peran suami. Secara umum Ibu/ibu mertua tidak mengetahui perkembangan pemberian ASI eksklusif pada bayi yang sebaiknya diberikan hingga bayi mencapai usia 6 bulan. ${ }^{4}$

Hasil penelitian ini menunjukkan bahwa Ibu yang tidak mencari informasi mengenai ASI memiliki hubungan yang signifikan terhadap pemberian ASI eksklusif. Sumber informasi yang digunakan berkaitan dengan keterpaparan informasi mengenai ASI. Informasi mengenai asi merupakan hal yang wajib didapatkan ibu agar ibu sadar bahwa sebuah perilaku penting untuk diadaptasi. Informasi yang didapat oleh responden berkaitan dengan niat atau kemauan responden untuk memberikan ASI pada bayinya. $^{10}$

Analisis bivariat menunjukkan bahwa tidak terdapat hubungan yang signifikan antara pengetahuan ibu, tingkat pendidikan ibu dan tingkat pendidikan suami dan pemberian ASI eksklusif. Hal ini mendukung penelitian yang dilakukan oleh Sartono bahwa pengetahuan ibu dan pendidikan ibu tidak berhubungan dengan pemberian asi eksklusif karena mereka berhasil menyusui secara eksklusif lebih karena mengikuti anjuran menyusui dari penolong persalinan yang menumbuhkan niat pribadi untuk menyusui bayinya. Selain itu didukung oleh kondisi dimana pada saat setelah persalinan Asi segera keluar sehingga segera bisa diberikan kepada bayi dan bayi tidak sempat diberikan susu formula atau dengan kata lain berhasil tidaknya menyusui eksklusif berhubungan dengan pelaksanaan manajemen laktasi yang dilaksanakan oleh petugas penolong persalinan. pendapat lain yang mendukung penelitian ini juga didukung oleh Fikawati dan Syafiq yang menyatakan bahwa pemberian ASI eksklusif tidak didasari oleh pengetahuan mengenai manfaat gizi dan kesehatan ASI eksklusif tetapi karena adanya tradisi yang sudah membuktikan kebaikan asi secara umum, misalnya ketika anak masih kecil perkembangannya lebih cepat dari anak lain. ${ }^{4}$

Jenis pekerjaan ibu pada penelitian ini tidak memberikan hubungan yang signifikan terhadap pemberian asi eksklusif. Hal ini sejalan dengan penelitian Purnamawati bahwa tidak ada hubungan antara ibu bekerja dan pemberian asi eksklusif pada bayi. ${ }^{12}$ Pemberian ASI eksklusif di kota sudah banyak digantikan dengan susu botol atau susu formula. Meskipun ibu tidak bekerja tetapi ibu terpengaruh oleh lingkungan keluarga untuk memberikan makanan tambahan sebelum bayi berusia kurang dari 6 bulan. $^{13}$

Sikap ibu menunjukkan tidak memiliki hubungan yang spesifik terhadap pemberian ASI eksklusif. Hal ini dikarenakan menyusui merupakan perilaku yang bersifat naluri keibuan untuk menyusui bayinya, tetapi sikap ingin menyusui secara eksklusif akan berubah ketika ibu menghadapi masalah menyusui seperti ASI belum keluar, ASI sedikit, bentuk puting, puting lecet, anak rewel, dan kurangnya dukungan dari suami, keluarga, dan petugas kesehatan. ${ }^{14}$ Kemudian Sears et.al menyebutkan bahwa jika seseorang tidak selamanya konsisten karena pengaruh sikap dan perilaku akan berkembang akan dipengaruhi oleh kekuatan sikap, stabilitas sikap, relevansi sikap terhadap perilaku dan tekanan situasi. ${ }^{15}$ 


\section{KESIMPULAN DAN SARAN}

Pada penelitian ini menunjukkan bahwa praktek pemberian ASI eksklusif di kota Palembang masih belum mencapai target yang menjadi indikator Indonesia Sehat tahun 2017 dengan target yaitu $80 \%$, selanjutnya dari hasil analisis hubungan menunjukkan responden yang memiliki jumlah anak $\leq 2$ orang, dukungan suami dan dukungan mertua berhubungan secara signifikan terhadap pemberian ASI eksklusif pada bayi. Sedangkan ibu yang tidak mencari informasi, tingkat pengetahuan ibu, jenis pekerjaan ibu dan sikap ibu tidak menunjukkan adanya hubungan terhadap pemberian ASI eksklusif pada bayi. Meskipun demikian variabel yang diketahui tidak ada hubungan dengan pemberian ASI ekslusif memiliki potensi terhadap upaya

\section{DAFTAR PUSTAKA}

1. Roesli U. Inisiasi Menyusui Dini Plus ASI Eksklusif, Jakarta : Pustaka Bunda. 2008.

2. Baker EJ, Sanei LC, Farmklin N. Early Initiation of And Exclusive Breasfeeding ini Large-Scale, Community Breast Programmes ini Bolivia and Madagascar Journalof Health, Population and Nutrition, 2006: 24 (4): 530-9

3. Edmond KM, Zandoch C, Qulglay MA, et al., Delayed Breastfeeding Inisiation Increase Risk Of Neonatal Mortality, Journal Of Pediatrics, 2006; 117 (3) : e380-6

4. Fikawati $\mathrm{S}$ dan Syafiq A., Hubungan antara Immediate Beastfeeding dan ASI Eksklusif 6 bulan. Jurnal Kedokteran Trisakti Vol. 22 (2)

5. Forster DA, McLachan HL, and Lumely J., Factor Assosiasited With Breasfeeding at Six Months in a Group of Australian WomenInternasional Breastfeeding Journal, 2006; 1:18

6. Lelia Kusuma Astuti Studi Deskriptif TingkatPengetahuan Ibu Menyusui pemberian ASI eksklusi yang dilakukan ibu.

Pemegang kebijakan dan para ibu dan calon ibu diharapkan meningkatkan pemahaman melalui berbagai program dengan mempertahankan upaya pendidikan kesehatan dan meningkakan upaya tersebut dengan mengembangkan metode dan media, sehingga sikap dan tindakan pemberian ASI Ekslusif dapat memenuhi target yang ditetapkan oleh pemerintah. Selain itu lingkungan terdekat ibu seperti suami, orang tua dan mertua sangat diperlukan dukungan totalitas kepada ibu untuk meeberikan ASI ekslusif, dan tak kalah penting lingkungan temoat kerja juga perlu adanya support dengan memberikan cuti atau jika tidak menyediakan ruang menyusui atau ruang pumping ASI di tempat-tempat kerja.

Tentang ASI Eksklusif Di Puskesmas Cilacap Utara, Jurnal KES MAS UAD. 2009; Vol. 3 (3)

7. Agus Hartono, dkk. Hubungan Pengetahuan Ibu, Pendidikan Ibu dan Dukungan Suami dengan Praktek Pemberian Asi Eksklusif di Kelurahan Muktiharjo Kidul Kecamatan Telogosari Kota Semarang, Jurnal Gizi Universitas Muhammadyah Semarang November 2012, Vol. 1(1) http://jurnal.unimus.ac.id

8. Ifa Sari, dkk. Hubungan Tingkat Pengetahuan Ibu Bekerja Dengan ASI Eksklusif Di Desa Sumberrejo Kecamatan Miranggen Kabupaten Demak, 2011. http://digilib.unimus.ac.id

9. Yekfi Widodo, dkk, Strategi Peningkatan Praktik Pemberian ASI Eksklusif, PGM 2003,26(1): 31- 38

10. Sandra Fikawati, dkk. Kajian Implementasi dan Kebijakan Air Susu Ibu (ASI) Eksklusif dan Inisiasi Dini di Indonesia, Makara Kesehatan. 2010; Vol. $14,(1): 17-24$

11. Etika Ratna Noer, dkk. Praktik Inisiasi Menyusui Dini dan Pemberian ASI Eksklusif Studi Kualitatif pada Dua 
Puskesmas, Kota Semarang, Fakultas Kedokteran Universitas Diponegoro dan Ikatan Dokter Indonesia Wilayah Jawa Tengah. 2011.

12. Shanty Wulandari, dkk Hubungan Pengetahuan dan Sikap Dengan Pemberian ASI Eksklusif Oleh Ibu-Ibu Yang Bekerja Sebagai Perawat Di RS Al Islam Kota Bandung, 2009. Vol 10 No,IXI.

13. Retno Sari Mumpuni, dkk. Pengaruh Inisiasi Menyusui Dini (IMD) dan Faktor Sosial Demografi Terhadap Ketahanan Pemberian ASI Eksklusif, E-Journal
WIDYA Kesehatan Dan Lingkungan. 2016; Vol. 1 (2).

14. Prihatin Setyawati, dkk. Pengaruh Inisiasi Menyusui Dini (IMD) Terhadap Lama Pengeluaran Plasenta Pada Kala III Persalinan Di RB Kabupaten Rejowinangun Utara Kota Magelang Jurnal Keperawatan Maternitas. 2013; Vol. 1 ( 2) : 78-84

15. Hikmah Nurmaralita, dkk. Pola Pemberian ASI Pada Bayi IMD di Kelurahan Subulussalam Kota Kecamatan Simpang Kiri Kota Subulussalam Tahun 2012 